\title{
Um médico em transformação...: os álbuns de formatura nos anos 1960
}

Com o final da II Guerra Mundial em 1945, mesmo sob a ameaça da Guerra Fria, lembra Hobsbawm (1995, p.254) "que muita gente sabia que os tempos de fato tinham melhorado". No plano social, novas demandas vindas de uma classe média em ascensão fortaleciam ações sociopolíticas para se estenderem os benefícios materiais sobretudo para aqueles que não tinham entrado no desenvolvimento e na modernização (Oliveira, 2002). Nesse contexto, a medicina e seu aparato tecnológico - educacional e prático - foram alargando seu espaço de atuação; os hospitais se expandiam e a saúde foi integrando, cada vez mais, a pauta das novas políticas a serem testadas e desenvolvidas (Mota et al., 2004). Em suas apreciações sobre o período, Dalmaso mostrou que ocorreria uma expansão da oferta de cuidados médicos e uma crescente produção, vindas da Europa e América do Norte, de medicamentos e equipamentos médico-hospitalares. Somam-se ao incremento desses recursos: a simplificação do acesso aos serviços e especialistas, a expansão da cobertura a uma maior parte da população e a constituição da saúde em mercado de prestação de serviços (Dalmaso, 1998).

Entre as inovações paradigmáticas propostas para a medicina e a saúde, deramse postulações preventivistas como capazes de enfrentar as novas pendências sociais (Donnangelo, Pereira, 2003; Schraiber, 1989). Em 1952, realizou-se, em Colorado Springs, um congresso com os principais representantes das escolas médicas norte-americanas, destinado a iniciar uma ampla reforma curricular dos cursos médicos, privilegiando as teorias preventivistas. A repercussão dessa nova política educacional médica levou a um movimento internacional: em Nancy (França), 1952; em Gotemburgo (Suécia), 1953; patrocinado pela OMS em Viña del Mar (Chile), 1955, e em Tehuacán (México), em 1956. Organizava-se, assim, um movimento de articulação das abordagens interdisciplinares no campo médico e de saúde. As demandas sociais entravam em pauta, num diálogo com campos até então estranhos aos assuntos médicos e sanitários, tais como os estudos antropológicos do processo saúde-doença.

Em São Paulo, a Faculdade de Medicina da USP dava novos direcionamentos ao campo do ensino e da pesquisa em seu Hospital das Clínicas, que se ampliava velozmente, como resultado do desenvolvimento das tecnologias médicas empregadas e das demandas sociais, fruto do próprio crescimento da cidade de São Paulo, já que, "uma nova conjuntura econômica, cultural e política promoveria na

${ }^{1}$ Museu Histórico, Faculdade de Medicina, Universidade de São Paulo. Av. Dr. Arnaldo, 455, 4. andar, Pinheiros, São Paulo, SP, Brasil. amota@museu.fm.usp.br 
CRIAÇÃO

década de 1960 um reordenamento profundo da sociedade brasileira, do qual evidentemente a Faculdade de Medicina não seria poupada" (Marinho, 2006, p.108).

Já sobre a produção iconográfica dessas transformações, bastante divulgada em diversos aspectos, podemos sempre encontrar uma documentação ainda não publicada e em aberto ao pesquisador. Nesse sentido, o "Álbum de Formatura" do corpo discente dos médicos, mesmo se apresentando em sua forma fechada e hermética, pode ser reveladora do campo profissional e do momento vivido pela sociedade em que está inserida. Segundo Kossoy (1993), a fotografia é plena de ambiguidades, portadora de significados não explícitos e de omissões pensadas, calculadas, que aguardam pela competente decifração.

Sob a guarda do Museu Histórico "Carlos da Silva Lacaz" da FMUSP, essas séries de imagens iconográficas, dos anos 1960, compreendidas como "vetores para a investigação de aspectos relevantes na organização, funcionamento e transformação de uma sociedade" (Menezes, 20063, p.34), oferecem uma representação até então desconhecida dos "novos médicos". Nesse sentido, o resgate histórico dessas séries pode aprimorar nosso olhar sobre o passado, ao mesmo tempo em que abre espaço para o conhecimento de seus significados mais intrincados.

Tais imagens passaram a receber uma configuração atualizada, deixando as vestes talares de outrora, para a divulgação de um profissional em ação, dentro de seu campo de atuação. Eficiência e um certo desprendimento invadiram as posturas, os sorrisos e as atitudes do esculápio. A tradição investia-se de um novo corpo simbólico, adaptando-se aos tempos modernos, mesmo que pudessem conservar, em muitos aspectos, velhos costumes.

\section{Referências}

AROUCA, S. Dilema preventivista: contribuição para a compreensão e crítica da medicina preventiva. São Paulo: Ed. Unesp, 2003.

DALMASO, A.S.W. Estruturação e transformação da prática médica: técnica e ciência na segunda metade do século XX. 1998. Tese (Doutorado) - Departamento de Medicina Preventiva, Faculdade de Medicina, Universidade de São Paulo, São Paulo. 1998.

DONNANGELO, M.C.F.; PEREIRA, L. Saúde e sociedade. São Paulo: Duas Cidades, 1976.

HOBSBAWM, E.J. A era dos extremos: o breve século XX, 1914-1991. São Paulo: Cia. das Letras, 1995.

KOSSOY, B. Estética, memória e ideologia fotográficas. Acervo, v.6, n.12, 1993.

MARINHO, M.G.S.M.C. Trajetória da Faculdade de Medicina da Universidade de São Paulo: aspectos históricos da Casa de Arnaldo. São Paulo: Faculdade de Medicina/USP, 2006.

MENEZES, U.T.B. Fontes visuais, cultura visual, história visual. Balanço provisório, propostas cautelares. Rev. Bras. Historia, v.23, n.45, p.11-36, 2003.

MOTA, A. et al. Contribuições pragmáticas para a organização dos humanos em saúde e para a história da profissão médica no Brasil à obra de Cecília Donnangelo. Brasília: Ministério da Saúde/OPS, 2004.

OLIVEIRA, L.L. Tempos de JK: a construção do futuro e a preservação do passado. In: MIRANDA, W.M. (Org.). Anos JK: imagens da modernidade. São Paulo: Imprensa Oficial, 2002. p.31-44.

SCHRAIBER, L.B. Educação médica e capitalismo. São Paulo: Hucitec/Abrasco, 1989. 